\title{
Hyperlipoproteinemia(a) and Hyperhomocysteinemia in an Young Female with Cerebrovascular Accident
}

\author{
Krishna Sen ${ }^{1}$, Anjan Adhikari2 ${ }^{*}$, Moumita Ray ${ }^{2}$ \\ 'Department of Medicine, Murshidabad Medical College, Berhampur, Dist. Murshidabad-742101, West Bengal, INDIA. \\ 2Department of Pharmacology, R. G. Kar Medical College, Kolkata-700004, West Bengal, INDIA.
}

\begin{abstract}
Background: Hyperhomocysteinemia is a recognized cause of cerebrovascular accident in young, in the Indian subcontinent population. But high lipoprotein(a) is not so much common and though associated with atherogenesis, no positive correlation is established till now between these. Case report: A patient presented with sudden onset of left sided hemiplegia without any recognized risk factor of atherosclerosis but a past history of miscarriage attended the Emergency in a tertiary care hospital. Her blood parameter shows Homocysteine level $19.51 \mu \mathrm{mol} / \mathrm{L}$ and lipoprotein(a) level $580 \mathrm{mg} / \mathrm{L}$. Computed tomography (CT) scan showed infraction in the right basal ganglion which was confirmed by Magnetic Resonance Imaging (MRI) later on. Conclusion: It is a unique type of case report as Hyperlipoproteinemia(a) is not a recognized cause of cerebrovascular accident (CVA). More study require to establish the correlation between
\end{abstract}

hyperlipoproteinemia(a) \& hyperhomocysteinemia and cerebrovascular accident.

Key words: Cerebrovascular Accident, Hyperhomocystienemia, Hyperlipoprotienemia(a)

Correspondence:

Dr. Anjan Adhikari,

Associate Professor, Department of Pharmacology, R. G. Kar Medical College, 1, Kshudiram Bose Sarani, Kolkata-700004, INDIA.

Mob: 09831012503

E-mail: dradhikarianjankolkata@gmail.com, iacsm.rgkmc@gmail.com DOI: 10.5530/jyp.2017.9.27

\section{INTRODUCTION}

It has been found for last few years that elevated total homocysteine concentration is associated with ischaemic stroke. ${ }^{1}$ In various studies it has been also found that homocysteine has the cytotoxic and thrombophilic effects on vascular endothelium. In a few study it is also established that non fasting serum total homocysteine more than $14 \mathrm{micromol} / \mathrm{L}$ is associated with high incidence of stroke. ${ }^{2}$ It is also well established that increased lipoprotein(a) is a predictor of premature coronary artery disease and also ischaemic stroke. ${ }^{3}$ The present case was a 26 years lady presented with ischaemic stroke with increased blood homocysteine and lipoprotein(a) level without any other risk factor.

\section{CASE REPORT}

A 26 years lady presented with ischaemic stroke with increased blood Homocysteine and lipoprotein(a) level without any other risk factor was reported in the Emergency of a tertiary care hospital at Kolkata, India. The young lady, resident of West Bengal, India, married, with two children attended the 'Emergency department' with sudden onset weakness of left side of body with deviation of angle of mouth. There was no history of convulsion, unconsciousness. History suggested she was normotensive, nondiabetic, nonobese with no history of dyslipidemia. No past history of tuberculosis or any seizure disorder was there. She had a history of miscarriage 4 years back. General examination showed no abnormality. Neurological examination revealed, patient was alert, conscious, cooperative. Higher functions were normal. There was complete hemiplegia in the left side of body with planter extensor in left side. Other systemic examinations were normal. Investigations revealed: Haemoglobin $(\mathrm{Hb}) 11.65 \mathrm{gm} \%$, total lymphocyte count (TLC) 8400 (N64, L30, E03, M03) \& adequate platelet, erythrocyte sedimentation rate (ESR): $04 \mathrm{~mm} / \mathrm{1}^{\text {st }} \mathrm{hr}$. Red blood cell (RBC): 88 $\mathrm{mg} \%$, urea: $28 \mathrm{mg} / \mathrm{dL}$, creatinine: $0.4 \mathrm{mg} / \mathrm{dL}$, with normal lipid profile \&, normal liver function test (LFT), Na: $142 \mathrm{meq} / \mathrm{L}, \mathrm{K}: 4.5 \mathrm{meq} / \mathrm{L}$. Her prothrombin time, international normalized ratio (INR) was 1.08, antinuclear antibody (ANA)- negative, human immunodeficiency virus (HIV) antibodies - nonreactive, C-reactive protein (CRP) negative, rapid plasma regain (RPR) - negative. Her electrocardiography (ECG) was normal, chest X-ray normal and echocardiography revealed no abnormality. CT scan (noncontrast) revealed improperly defined inhomogeneous hypodensity in right basal ganglion region without any significant oedema and mass effect. MRI scan was subsequently done [Figure 1].

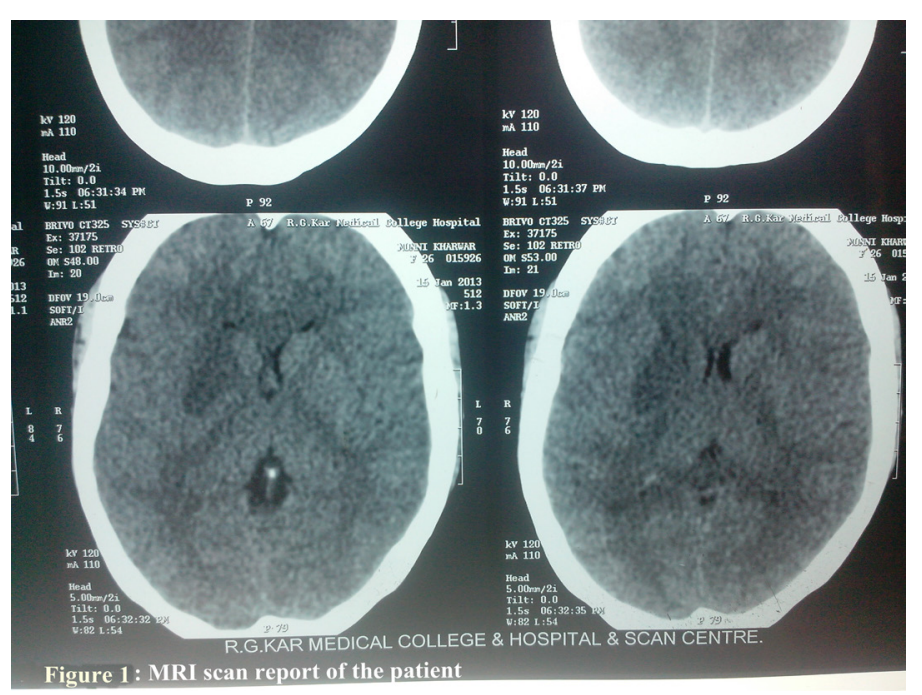

Figure 1: MRI scan report of the patient.

This is an open access article distributed under the terms of the Creative Commons Attribution-NonCommercial-ShareAlike 4.0 License, which allows others to remix, tweak, and build upon the work non-commercially, as long as the author is credited and the new creations are licensed under the identical terms. 
Ultrasonography (USG) abdomen revealed no obvious abnormality and carotid doppler showed ratio of peak systolic velocity (PSV)/end diastolic velocity (EDV) in right \& left internal carotid artery were respectively1.3\&1.24(normal). Blood investigation revealed; protein C: $90 \mathrm{IU} / \mathrm{dL}$ (normal $65-135 \mathrm{IU} / \mathrm{dL}$ ) protein S: 74U/dL (Normal value males - $>73 \mathrm{U} / \mathrm{dL}$, females - $>63 \mathrm{U} / \mathrm{dL}$ ), serum Homocysteine level: $19.51 \mu \mathrm{mol} / \mathrm{L}$ (normal range for adult female: $3-12 \mu \mathrm{mol} / \mathrm{l}$ ), and serum lipoprotein(a) level: $580 \mathrm{mg} / \mathrm{L}$ (normal $<300 \mathrm{mg} / \mathrm{L}$ ). Subsequently folic acid and vitamin $B_{6}$, vitamin $B_{12}$ estimation was done and it revealed folic acid $11 \mathrm{ng} / \mathrm{ml}(2.5$ to $20 \mathrm{ng} / \mathrm{ml})$, vitamin $B_{12} 361 \mathrm{pg} /$ $\mathrm{ml}\left(200\right.$ to $900 \mathrm{pg} / \mathrm{ml}$ ) and vitamin $\mathrm{B}_{6}$ was $27 \mathrm{microgram} / \mathrm{dL}$ (5 to 50 microgram/dL). Thyroid test was done and it revealed normal level. Patient was treated with supportive measures, conservative therapy including Aspirin \& Atorvastatin with physiotherapy. Subsequently, patient was discharged in stable condition with vitamin $B_{6}$, vitamin $B_{12}$ \& folic acid supplementation.

\section{DISCUSSION}

Homocystiene acts as an atherogenic and thromophilic agent. ${ }^{4}$ Secondary elevations of homocystiene are seen in increasing age, smoking, in post menopausal women, renal failure, hypothyroidism, leukemia, inflammatory bowel disease \& psoriasis. ${ }^{5}$ Therapy with Methotrexate, Isoniazide / Isonicotinylhydrazine (INH), nitrous oxide \& some anti epileptic drugs also cause secondary elevation of Homocystiene, presumably due to interference with folate metabolism. Though classic homocysteiuria results in Homocysteine levels of $>100$ umol/L. ${ }^{5}$ lesser degrees of raised serum homocysteine (in absence of significant homocysteinuria) have been described \& found to be associated with cerebrovascular, coronary, peripheral vascular disease, and deep vein thrombosis. These patients are considered milder homozygotes/ heterozygotes for cystathione beta synthase or methylene tetrahydrofolatereductase (MTHFR) deficiency ${ }^{6,7}$ It has been found that homozygous MTHFR mutation is associated with various complications in pregnancy like preeclampsia, placental abruption, but whether recurrent pregnancy loss is associated or not, yet to be proved. ${ }^{7}$ Though prospective randomized controlled trial of lowering serum homocysteine levels with supplements of folic acid, vitamin $\mathrm{B}_{6}$ \& vitamin $B_{12}$ against a placebo over a 5 year period in patients with vascular disease or diabetes have not however shown any reduction in major cardiovascular events, ${ }^{8}$ meta analysis has suggested that folic acid supplementation reduces the risk of stroke by $18 \%$.

\section{CONCLUSION}

Present study of a 26 yrs lady with hyperhomocysteinemia \& hyperlipoproteinemia(a), without any other biochemical derangement, suffered from cerebrovascular accident. Hyperlipoproteinemia(a) is not a recognized cause of cerebrovascular accident (CVA). More study require to establish the correlation between hyperlipoproteinemia(a) \& hyperhomocysteinemia and cerebrovascular accident.

\section{ABBREVIATIONS USED}

$\boldsymbol{\mu m o l / L : ~ M i c r o m o l e ~ p e r ~ l i t e r ; ~ A N A : ~ A n t i n u c l e a r ~ a n t i b o d y ; ~ C R P : ~ C - r e - ~}$ active protein; CT: Computed tomography; CVA: Cerebrovascular Accident; dL: Deciliter; E: Eosinophil; ECG: Electrocardiography; EDV: End diastolic velocity; ESR: Erythrocyte sedimentation rate; gm: Gram; Hb: Haemoglobin; HIV: Human immunodeficiency virus; hr: Hour; INR: International normalized ratio; IU/dL: International Unit per deciliter; L: lymphocyte; LFT: liver function test; M: Monocyte; meq/L: Milliequivalent per liter; mg: Milligram; mg/dL: Milligram per deciliter; mg/L: Milligram per liter; mm: Millimeter; MRI: Magnetic Resonance Imaging; MTHFR: Methylene tetrahydrofolatereductase; N: Neutrophil; ng/ml: Nanogram per milliiliter; pg/ml: Picogram per milliliter; PSV: peak systolic velocity; RBC: Red blood cell; RPR: rapid plasma regain; TLC: Total lymphocyte count; U/dL: Unit per deciliter; USG: Ultrasonography.

\section{REFERENCES}

1. Hankey GJ, Eikelboom JW. Homocysteine and stroke. Curr Opin Neurol. 2001;14(1):95-102. http://dx.doi.org/10.1097/00019052-200102000-00015.

2. Bostom AG et al. Non fasting plasma total homocysteine levels and stroke in cidence in elderly persons: The Framingham Study. Annals of Internal Medicine. 1999;131(5):352-5. http://dx.doi.org/10.7326/0003-4819-131-5-19990907000006 ; PMid:10475888.

3. Milionis HJ, Winder AF, Mikhailidis DP. Lipoprotein(a) and stroke, J Clin Pathol. 2000;53(7):487-96. http://dx.doi.org/10.1136/jcp.53.7.487; PMid:10961170 PMCid: PMC1731226

4. Marcucci R et al. PAl-1 and homocysteine, but not lipoprotein(a) and thrombophilic polymorphisms, are independently associated with the occurrence of major adverse cardiac events after successful coronary stenting. Heart. 2006:92(3):377-81. http://dx.doi.org/10.1136/hrt.2005.061895 ; PMid:15994914 PMCid:PMC1860841.

5. Varga EA, Sturm AC, Misita CP, Moll S. Homocysteine and MTHFR Mutations, Relation to Thrombosis and Coronary Artery Disease. Circulation. 2005; 111(19):e289-93. http://dx.doi.org/10.1161/01.CIR.0000165142.37711.E7; PMid: 15897349.

6. Ray JG, Shmorgun D, Chan WS. Common C677T Polymorphism of the Methylenetetrahydrofolate Reductase Gene and the Risk of Venous Thromboembolism: Meta-Analysis of 31 Studies. Pathophysiol Haemost Thromb. 2002;32(2):51-8. http://dx.doi.org/10.1159/000065076 ; PMid:12214149.

7. Rey E, Kahn SR, David M, Shrier I. Thrombophilic disorders and fetal loss: a meta-analysis. Lancet. 2003;361(9361):901-8. http://dx.doi.org/10.1016/S01406736(03)12771-7.

8. Lee M, Hong K, Chang C, Jeffrey L. Saver Efficacy of Homocysteine-Lowering Therapy with Folic Acid in Stroke Prevention: A Meta-Analysis. Stroke. 2010; 41(6):1205-12. http://dx.doi.org/10.1161/STROKEAHA.109.573410; PMid:20413740 PMCid:PMC2909661. 